\title{
Fluxes of water, sediments, and biogeochemical compounds in salt marshes
}

\author{
Sergio Fagherazzi ${ }^{1 *}$, Patricia L Wiberg ${ }^{2}$, Stijn Temmerman ${ }^{3}$, Eric Struyf ${ }^{3}$, Yong Zhao $^{4}$ and Peter A Raymond ${ }^{4}$
}

\begin{abstract}
Tidal oscillations systematically flood salt marshes, transporting water, sediments, organic matter, and biogeochemical elements such as silica. Here we present a review of recent studies on these fluxes and their effects on both ecosystem functioning and morphological evolution of salt marshes. We reexamine a simplified model for the computation of water fluxes in salt marshes that captures the asymmetry in discharge between flood and ebb. We discuss the role of storm conditions on sediment fluxes both in tidal channels and on the marsh platform. We present recent methods and field instruments for the measurement of fluxes of organic matter. These methods will provide long-term data sets with fine temporal resolution that will help scientists to close the carbon budget in salt marshes. Finally, the main processes controlling fluxes of biogenic and dissolved silica in salt marshes are explained, with particular emphasis on the uptake by marsh macrophytes and diatoms.
\end{abstract}

\section{Introduction}

The exchange of sediments, silica, and organic matter between terrestrial ecosystems and the ocean is an important theme in ecological and biogeochemical studies. As a widely distributed coastal ecosystem covering 200,000$400,000 \mathrm{~km}^{2}$ globally, salt marshes are highly productive [net ecosystem production (NEP) $=1,585 \mathrm{~g} \mathrm{C} \mathrm{m}^{-2}$ year $^{-1}$ ], rivaling tropical rainforests, due to abundant solar radiation, water, and nutrients provided by tidal water (Chmura et al. 2003; Duarte et al. 2005; Cai 2011). Tidal oscillations repeatedly flood salt marshes, giving rise to fluxes that bring water and constituents in and out of the system (Fagherazzi et al. 2012). This review focuses on fluxes of sediments, organic matter, and silica and their effects on both ecosystem functioning and morphological evolution of salt marshes. Particular attention is devoted to the feedbacks between physical and biological processes.

Salt marsh formation and persistence are dependent on the net flux of suspended sediment onto the marsh platform (Kirwan et al. 2010; Fagherazzi et al. 2012) and loss of salt marsh during storms (Mariotti and Fagherazzi 2010; Tonelli et al. 2010). Interactions between tidal flows and marsh vegetation promote deposition of sediment delivered to the marsh platform during flooding tides.

\footnotetext{
* Correspondence: sergio@bu.edu

${ }^{1}$ Department of Earth and Environment, Boston University, Boston, MA, USA Full list of author information is available at the end of the article
}

Sediment deposition, along with accumulation of autochthonous organic material, contributes to the vertical accretion necessary for a marsh surface to maintain its elevation above mean sea level as sea level rises (Reed 1989; Morris et al. 2002; Mudd et al. 2009). Thus, healthy salt marshes must be net sediment sinks.

The buried carbon in the sediment of salt marshes as well as other intertidal wetlands, which is called "blue carbon," is a significant carbon sink, sequestering in excess of 4.8-87.2 $\mathrm{Tg} \mathrm{C}$ year $^{-1}$ globally according to different estimations (Chmura et al. 2003; Duarte et al. 2005; McLeod et al. 2011). However, viewed in light of the global NEP of salt marshes of $634 \mathrm{Tg} \mathrm{C}$ year $^{-1}$, only a small portion is retained in marsh sediments, and most of the produced biomass decomposes or is exported via lateral tidal fluxes (Middelburg et al. 1997; Duarte et al. 2005; Sharitz and Pennings 2006; Hopkinson et al. 2012).

In addition to carbon, other nutrients are deposited and recycled in coastal salt marshes. Of these, silicon (Si) is an essential element for primary production by diatoms in estuaries and coastal seas (Struyf and Conley 2009). In this paper we give an overview of studies that demonstrate the importance of tidal marshes in the associated estuarine Si cycle. In particular, we discuss the present state of knowledge regarding Si fluxes between tidal marshes and adjacent estuarine and coastal waters.

The paper is organized as follows: in the section "Fluxes of water," we describe fluxes of water in salt marshes and 
put forward a simplified model for their computation. In "Fluxes of sediments," we focus on fluxes of sediments both in tidal channels and on the marsh platform. In "Fluxes of organic material," we discuss novel techniques to measure fluxes of organic matter, and in "Fluxes of silica," we present a review of recent results on fluxes of silica in salt marshes. A set of conclusions and future research needs closes this review in the section "Conclusions."

\section{Fluxes of water}

The amount of water that enters and exits a marsh in a tidal cycle is the tidal prism, which can be computed, to a first approximation, as the volume of water contained in the marsh between high and low tide (Figure 1A), and it can be written as (D'Alpaos et al. 2010):

$$
P=\int_{A}\left[h_{H}-\max \left(z, h_{L}\right)\right] d A
$$

where $A$ is the marsh area, $h_{\mathrm{L}}$ is the water elevation at low tide, $h_{\mathrm{H}}$ the water elevation at high tide, and $z$ the elevation of the marsh surface.

When tidal channels are not present, the transport of water between marsh and the surrounding coast occurs as a sheet flow on the marsh surface with very low water depths (French et al. 1995; Temmerman et al. 2005). This shallow flow favors the incision of creeks that, once scoured, capture more flow in a positive feedback that produces a network of dendritic channels dissecting the marsh platform (Fagherazzi and Furbish 2001; Fagherazzi and Sun 2004; D’Alpaos et al. 2005).

The water is thus carried to the marsh during flood and subsequently drained during ebb in two steps: during flood, the water first moves at relatively high speed in the channel network and then it spills on the platform (e.g., Christiansen et al. 2000; Davidson-Arnott et al. 2002; Temmerman et al. 2012). During ebb the opposite occurs, with the water first drained on the platform and then collected in the channels. As a result the morphology of the marsh and the distribution of channels have a strong influence on water fluxes.

If the total volume of water entering or exiting the marsh is regulated by the tidal prism, the discharge depends also on the speed at which this water is delivered to or collected from the marsh. The rate of flooding (drainage) depends in the first place on the tidal oscillation (see Figure 1B,C). In fact, by taking the temporal derivative of Equation 1, we obtain:

$$
Q=A(h) \frac{d h}{d t}
$$

where $A(h)$ is the hypsometric curve (the surface flooded at each elevation $h), Q$ is the discharge, and $d h / d t$ the derivative of the tidal oscillation. Here for simplicity we assume that the water fluxes in and out of the marsh are concentrated in the channels, although a considerable volume of water is transported as sheet flow from the marsh edge directly on the marsh platform (French et al. 1995; Temmerman et al. 2005).

This equation is defined as the static model (tub model) and was first presented by Boon (1975). Since then it has been extensively used in salt marsh hydrodynamics (e.g., D’Alpaos et al. 2006, 2007, 2010; Lawrence et al. 2004). This model implies that when there is a sharp increase in flooded area $A$, the discharge surges because more water is needed to flood a larger surface (or more water must be removed to drain it; see Figure 1B,C). As a

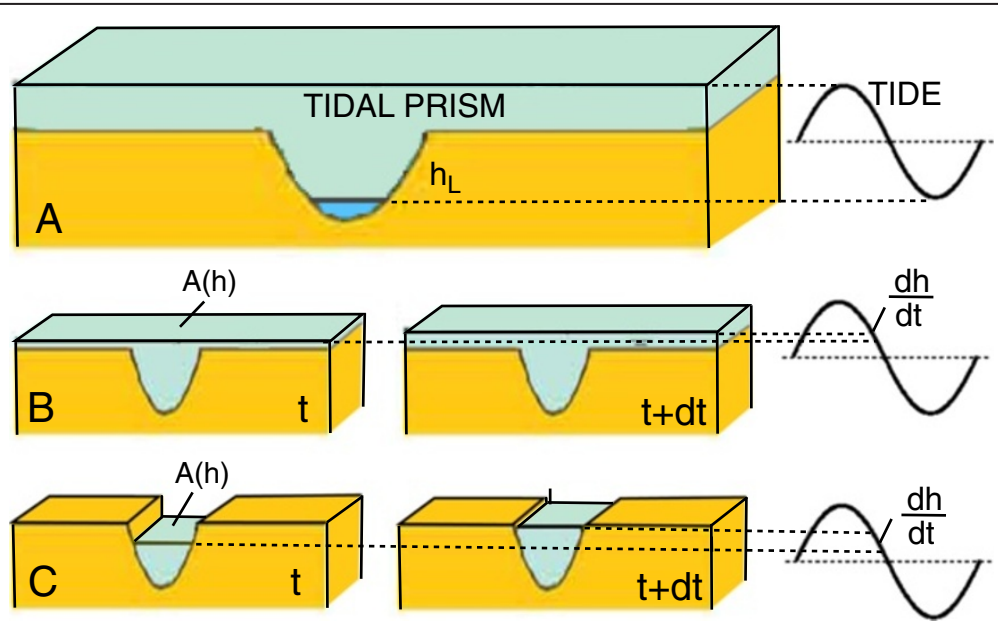

Figure 1 Cross-sectional representation of a salt marsh with a tidal channel and its relationship with respect to tidal oscillations. (A) Tidal prism, (B and $\mathbf{C}$ ) flooded area $A$ and rate of tidal elevation increase $d h / d t$ at two different instants in a tidal cycle. 
result, two distinct surges are occurring in the channels, one when the marsh platform is first flooded and one when the marsh platform is drained. These surges have been measured in salt marsh channels by several authors (Myrick and Leopold 1963; Bayliss-Smith et al. 1978; Healey et al. 1981; French and Stoddart 1992).

However, the static model implies that the water is instantaneously delivered to the entire marsh, when in reality it takes a finite time to reach each marsh location, depending on the travel path both within the channels and on the marsh platform. A modification of this model accounting for the delay due to the travel time was proposed by Fagherazzi et al. (2008), with the TIGER model:

$$
Q=\int_{0}^{t} A(h) \frac{d h}{d t} f(t-\tau) d \tau
$$

where $f$ is the distribution of travel time that can be computed by dividing the path length that a parcel of water needs to travel to reach each location by a characteristic velocity of the flow (see examples in Figure 2). In particular, the path followed by the water on the marsh platform can be computed using the method presented in Rinaldo et al. (1999).

It is important to note that the mean path length (unchannelized length) describes the drainage density of the tidal network (Marani et al. 2003). Equation 3 therefore links water discharge to drainage density. The introduction of a delay results in a peak discharge (surge) in flood occurring after the platform is flooded; in fact it takes time for the water to reach the farthest marsh locations and flood them. Similarly, the ebb surge takes place after the drainage of the marsh for a water elevation just below the marsh surface, and it is therefore confined in the channels (Figure 3). The stage-discharge and stage-velocity curves therefore present an asymmetry

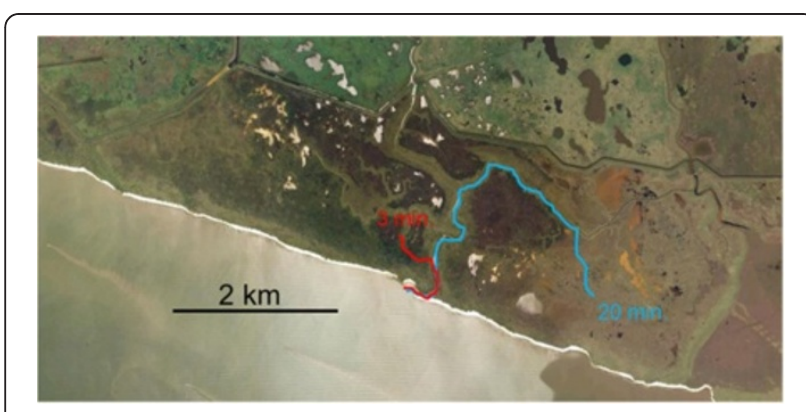

Figure 2 Two examples of water paths in a salt marsh, computed on the basis of water surface gradients (e.g., Rinaldo et al. 1999), and related travelling times. During flood, the water moves first in the channels and then on the marsh surface. The travelling times for all marsh locations need to be computed in order to determine the distribution $f$. as observed in the field by many researchers (Pethick 1980; Healey et al. 1981).

The introduction of a delay in the static model of Boon (1975) does not considerably change the magnitude of the peak discharge but has a strong impact on velocities, which are obtained by dividing the discharge by water depth. If the ebb surge takes place at lower water depths, then the velocity increases, resulting in the characteristic ebb dominance of marsh creeks (Friedrichs and Aubrey 1988). Since bottom shear stress scales with the square of the velocity, this flow asymmetry favors erosion and incision during ebb.

Moreover, the distribution of travel times contains information about salt marsh morphology and related ecosystems. For example, deep channels with high drainage density reduce the travel time of water parcels, while thick halophyte vegetation on the marsh platform slows the flow (Mudd et al. 2004; Temmerman et al. 2007). In fact plant stems and leaves convert kinetic energy into turbulent kinetic energy, increasing drag and reducing flow velocity (Nepf 1999). Temmerman et al. (2012) showed that after cutting marsh vegetation over a relatively large area ( $4 \mathrm{ha}$ ) the flow velocity on the platform increased by a factor of 2 to 4 , thus decreasing dramatically the travel time of water parcels.

The distribution of travel time is identical to the distribution of residence time of the water in the marsh, and it is therefore of extreme importance for biogeochemical cycles (Church 1986; Crump et al. 2004). The TIGER model (Equation 3 and Figure 4) represents an elegant method to determine the distribution of residence time from flow measurements in a channel cross section. It can also be used to detect shallow subsurface flows that move under the marsh platform and exit at the channel banks. In fact the long tail in the distribution of residence times represents such flows, which can therefore be isolated from the tidal surface water. These flows are very important for marsh biogeochemistry since they are rich in solutes and sediments (Wilson and Morris 2012).

\section{Fluxes of sediments}

In low marsh environments, where mineral sedimentation is greatest, daily tides inundate the marsh surface. Sediment suspended in the water flooding a low marsh can be the product of wave-driven resuspension in adjacent bays or tidally driven resuspension in tidal creeks.

\section{Sediment fluxes in tidal channels}

Most sediments enter the marsh through tidal channels. Similarly to the water fluxes discussed in the previous section, we can focus on the sediment fluxes entering and exiting a channel cross section and use them to 


\section{High Water}

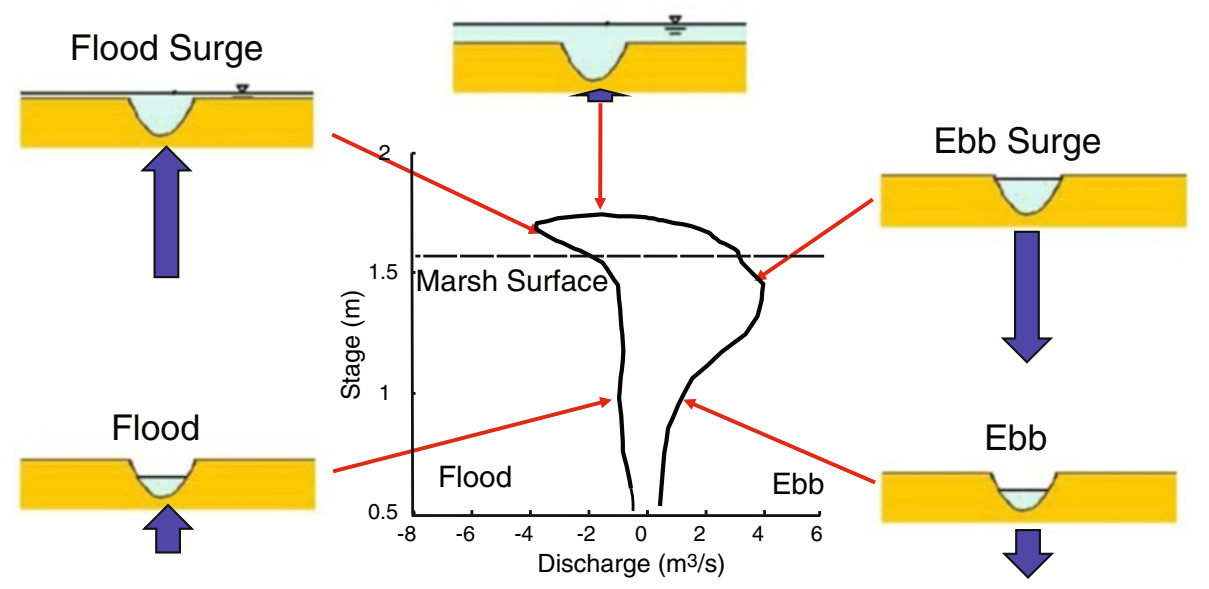

Figure 3 Stage-discharge relationship for a salt marsh channel. The blue arrows indicate the magnitude and direction of the discharge. The flood surge occurs for a water elevation just above the elevation of the marsh platform, while the ebb surge takes place when the water elevation is just below the elevation of the marsh surface.

determine the total sediment budget of a salt marsh. The sediment input in a marsh can be expressed as:

$$
V_{S}=\int_{t_{\text {low }}}^{t_{\text {high }}} C_{s} Q d t
$$

where $V_{\mathrm{S}}$ is the total volume of sediments entering the channels during flood, $C_{\mathrm{s}}$ is the sediment concentration in the water column, $t_{\text {low }}$ is the instant of low-tide slack water and $t_{\text {high }}$ is the instant of high-tide slack water. Equation 4 shows that two functions are essential to import large amounts of sediments in a marsh: a large water discharge during flood and, more importantly, high concentrations of suspended sediment. These sediments need to be in suspension near the channel entrance, so that when the tide is rising they are conveyed in the channel and subsequently deposited on the marsh platform. Wind waves and tidal currents are ideal processes for sediment resuspension and transport in areas adjacent to salt marshes. Waves are particularly effective in remobilizing sediments on tidal flats, where shallow water depths result in large wave-induced bottom shear stresses (Carniello et al. 2005; Fagherazzi et al. 2007). Measurements along the muddy Louisiana coastline show that the concentration of sediments entering a marsh channel is proportional to the significant wave

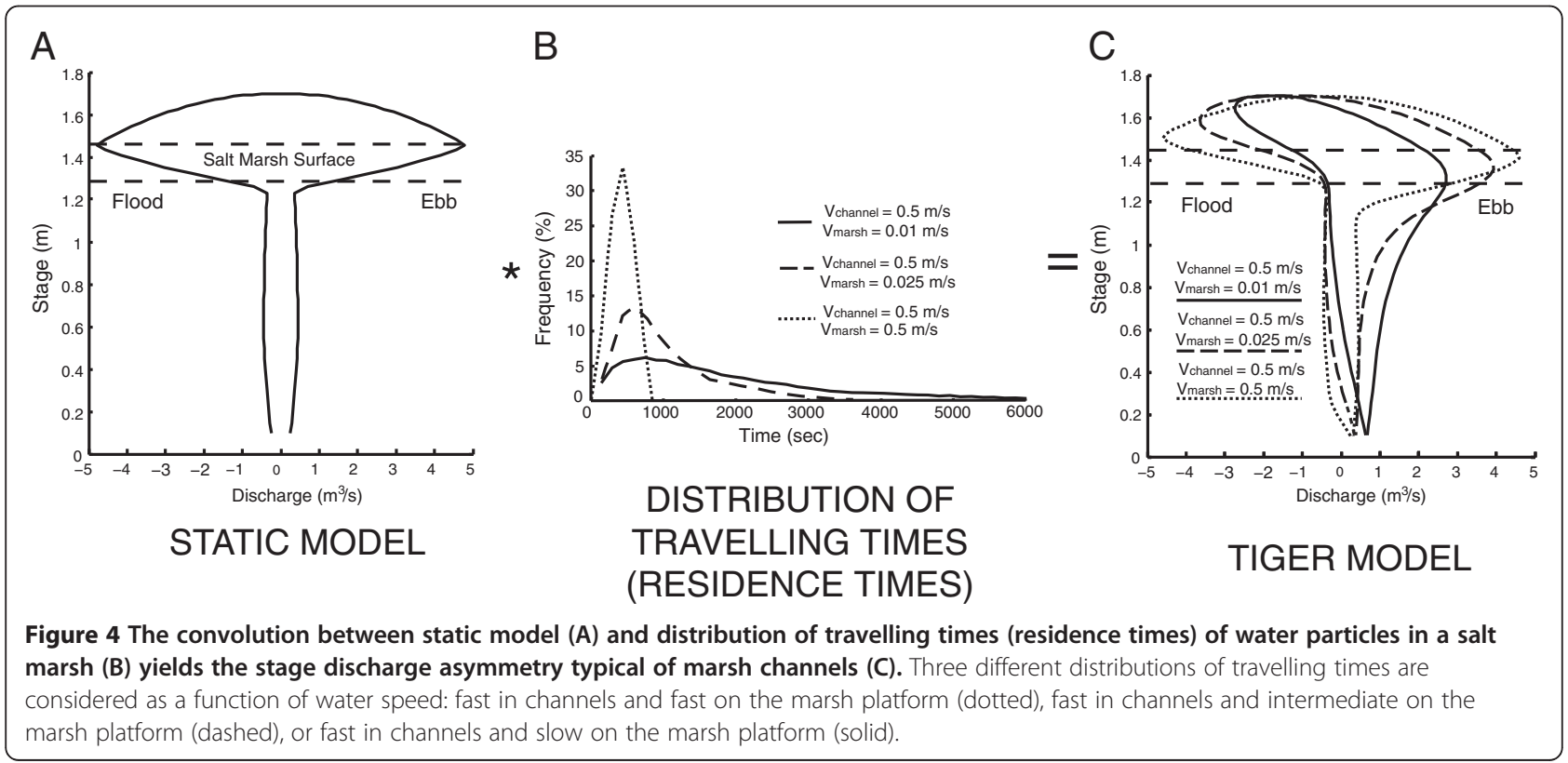


height in the bay in front of the channel (Fagherazzi and Priestas 2010; see Figure 5A).

A storm surge therefore represents an ideal event for sediment input in a marsh (e.g., Cahoon 2006; Reed 1989; Turner et al. 2006): the strong wind associated with the storm produces waves that resuspend fine sediments in front of marshes, and the wind and wave setup increases the maximum tide level and thereby the water discharge during flood in the channels (by increasing the tidal prism; see Equations 1,2). Therefore during a storm surge both discharge and sediment concentrations of the entering water are magnified, augmenting the total volume of sediment imported in the marsh (Equation 4).

This mechanism is well accepted in marsh studies, with several authors indicating storm conditions as ideal for marsh accretion (e.g., Reed 1989). However, sediment input during flood represents only half of the sediment budget. In fact sediments are exiting the marsh through the channels during the subsequent ebb flow. The same physics governs the export of sediments, and Equation 4 is still valid but now the integral is evaluated from $t_{\text {high }}$ to $t_{\text {low }}$.

The main difference is that the sediment concentration of the exiting flow is now independent of the hydrodynamic conditions in the adjacent bays and tidal flats but is governed by physical processes mobilizing sediments within the salt marsh. Wind waves are negligible on marsh platforms, given the shallow water depths and the damping effect of vegetation (Möller et al. 1999). Therefore only tidal currents triggering high velocities are potentially responsible for sediment mobilization on the marsh surface during ebb, although field evidence seems to indicate that this effect is limited. Most of the sediment is therefore eroded and resuspended from the channels bottom and banks, where the velocities are high and vegetation does not protect the substrate. Data from Louisiana confirm that sediment concentration in the water exiting a marsh during ebb is proportional to the tidal velocity in the channel (Figure 5B) (Fagherazzi and Priestas 2010).

The discharge asymmetry outlined in the previous section enhances sediment erosion during ebb, since the peak in discharge occurs in the channels for shallow water depths thus augmenting flow velocity and bottom shear stresses (Figure 3). Storm surges are therefore excellent events also for the export of sediments, since all the water accumulated in the marsh during the surge will exit the system, giving rise to high ebb velocities and bottom stresses.

Moreover, given the low settling velocity of the fine material typical of marshlands, some of the sediment that was imported during flood might remain in suspension and exit the system during the following ebb. This is particularly true when the residence time of the water in the marsh is low, such as in marshes of small dimensions with a high drainage density (limited water paths), or when the water velocity is high and thus the travel time is short (large advection velocity). Again storm surges, by increasing flow velocities, decrease the likelihood of particle settling during high tide, reducing the potential accumulation of sediments on the marsh platform.

Best conditions for sediment accumulation are moderate storms that increase sediment resuspension near salt marshes, but don't trigger fast flows in the channels (Fagherazzi and Priestas 2010). On the contrary, for sediment export the worst conditions occur during meteorological low tides (setdowns), when wind blows water away from the coastline and a large volume of water exits the marsh system. The setdown leads to shallow water depths, which, combined with large discharges, results in velocities that erode sediments in the channels. The low water levels also trigger large gradients in groundwater pressure leading to seepage and piping at channel banks (Gardner 2005; Howes and Goehringer 1994).
A

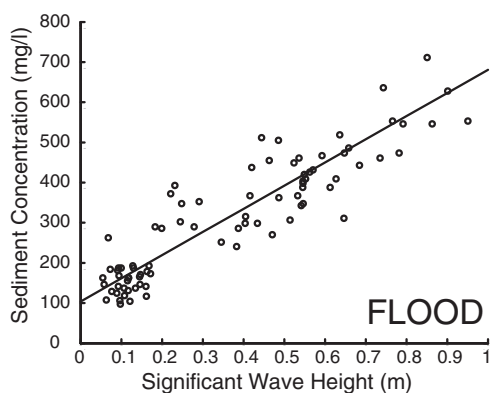

B

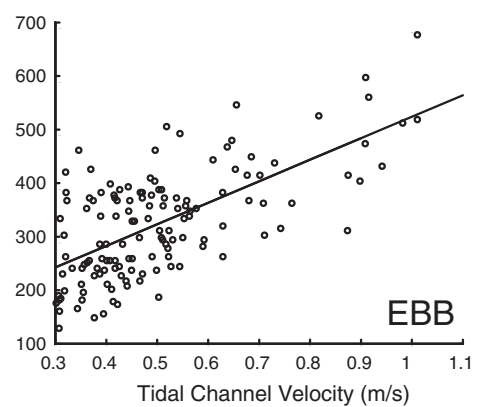

Figure 5 Relationships between sediment concentration and (A) significant wave height during flood and (B) tidal channel velocity during ebb in a marsh channel in Louisiana, USA. The wave height was measured in the bay just in front of the tidal channel (after Fagherazzi and Priestas 2010). 


\section{Sediment fluxes on the marsh platform}

Regardless of how large the wave and tidal bed shear stresses are in the adjacent bays and creeks, interactions between the flow and marsh vegetation reduce the velocities and turbulence in the flooding flows within a short distance of entering the vegetation (Leonard and Luther 1995; Christiansen et al. 2000), creating conditions favorable for deposition of the sediment in suspension. In addition, reductions in near-bed velocities and drag around plant stems lead to skin friction stresses that are almost always insufficient to entrain sediment from the marsh surface. Therefore the dynamics of sediment transport on the marsh surface are dominated by slow advection during tidal inundation, accompanied by particle settling and interception by vegetation stems.

A very simple model is useful for illustrating the factors controlling suspended sediment concentrations and deposition on the marsh platform. The model can be obtained by considering an advection-dispersion equation governing the dynamics of suspended sediments over the marsh platform and by neglecting the advective and dispersive terms so that the variation in time of the concentration equals the settling rate. Assuming that the water depth and flow velocity are constant in space and time and that the water column is well mixed, the evolution in concentration, $C_{\mathrm{s}}$, within the flooding tidal water can be expressed as:

$$
C_{s}=C_{s 0} \exp \left[-\left(w_{s} / h\right) t\right]=C_{s 0} \exp \left[-w_{s} x /(U h)\right]
$$

where $w_{\mathrm{s}}$ is settling velocity, $h$ is flow depth, $C_{\mathrm{s} 0}$ is initial concentration, $t$ is time, $x$ is distance from the creek bank or marsh edge, and $U$ is average flow velocity on the marsh. Deposition rate is given by the divergence of sediment flux, $-d\left(C_{s} U h\right) / d x$. It is clear from Equation 5 that concentration and hence deposition rate decrease along the flow path on the marsh platform and therefore with distance from the marsh edge (e.g., French et al. 1995; Leonard 1997; Reed et al. 1999; Temmerman et al. 2003). In fact the flow path on the marsh platform often coincides with the direction perpendicular to the marsh edge (Rinaldo et al. 1999; Marani et al. 2003). Peak flow velocities on the marsh surface tend to be small and do not vary much with tidal elevation or location on the marsh. Therefore settling velocity and flow depth are the primary controls of how much of the sediment entering the marsh is deposited.

These processes can be illustrated with an example from a microtidal (mean tidal range $=1.2 \mathrm{~m}$ ) low marsh site in coastal Virginia, USA (Christiansen et al. 2000). Peak flow velocities at the site average $\sim 0.2 \mathrm{~cm} / \mathrm{s}$ during rising and falling tides. For tidal amplitudes between 0.95 and $1.05 \mathrm{~m}\left(h_{\max } \approx 0.6 \mathrm{~m}\right)$, average peak suspended sediment concentration entering the marsh platform during flood is $85 \mathrm{mg} / \mathrm{L}$, which decreases by roughly $20 \% 3 \mathrm{~m}$ into the marsh (Christiansen et al. 2000). This rate of decrease is consistent with an average settling velocity of roughly $0.1 \mathrm{~mm} / \mathrm{s}$, the Stoke's settling rate for particles of $\sim 12 \mu \mathrm{m}$ diameter. Grain size distributions of marsh surface sediment near the marsh edge have a modal size of 15-20 $\mu \mathrm{m}$ (Christiansen et al. 2000).

The apparent agreement between modal bed grain size and estimated settling rate indicated above proves somewhat misleading when size distribution and its evolution across the marsh surface are taken into consideration. First, analysis of size distribution indicates that $70-75 \%$ of the sediment deposited within $10 \mathrm{~m}$ of the creek bank is deposited as flocs (Christiansen et al. 2000). Second, there was no significant grain size fining with distance from the creek bank, as would be expected from a simple application of Equation 1 to a disaggregated grain size distribution. Only if deposition is dominated by flocs can the grain size distribution of deposited sediment remain largely unchanged along the flow path.

Voulgaris and Meyers (2004) measured settling velocities and particle characteristics in a tidal channel in South Carolina, USA, and on the adjacent marsh. They found that suspended particles in the channel were predominantly flocculated, with average settling velocities of about $0.1 \mathrm{~mm} / \mathrm{s}$ during neap tides (mean diameter of $50 \mu \mathrm{m}$ ) and $0.25 \mathrm{~mm} / \mathrm{s}$ during spring tides (estimated mean diameters of $50-150 \mu \mathrm{m}$ ) in the tidal channel and an average settling velocity of $0.24 \mathrm{~mm} / \mathrm{s}$ on the marsh. Moskalski and Sommerfield (2012) measured particle characteristics on a salt marsh in Delaware and also found that flocs with median grain sizes of 50-150 $\mu \mathrm{m}$ predominated in marsh suspended sediment.

Sediment deposition measured on a Virginia coastal marsh site (Christiansen 1998) averaged $0.004 \mathrm{~g} \mathrm{~cm}^{-2}$ per tide near the tidal creek over a range of non-storm tidal conditions (Figure 6). This value is a little lower than deposition measured near a creek bank along a Delaware salt marsh of $\sim 0.01 \mathrm{~g} \mathrm{~cm}^{-2}$ per tide (Moskalski and Sommerfield 2012, assuming two tides per day).

Wind-enhanced tidal and wave-generated bed shear stresses result in higher concentrations of suspended sediment in the water flooding the marsh (Christiansen et al. 2000; Lawson et al. 2007; Fagherazzi et al. 2010) and longer inundation times. As a result, deposition rates are higher and deposition extends further into the marsh during storm tides (e.g., Cahoon 2006; Reed 1989; Turner et al. 2006). For example, measured deposition near the creek bank at the Virginia coastal marsh site increased by roughly an order of magnitude during a period that included a significant northeaster (Christiansen 1998; Figure 6). At that site, northeasterly winds occurred during $11 \%$ of the tidal cycles but were 

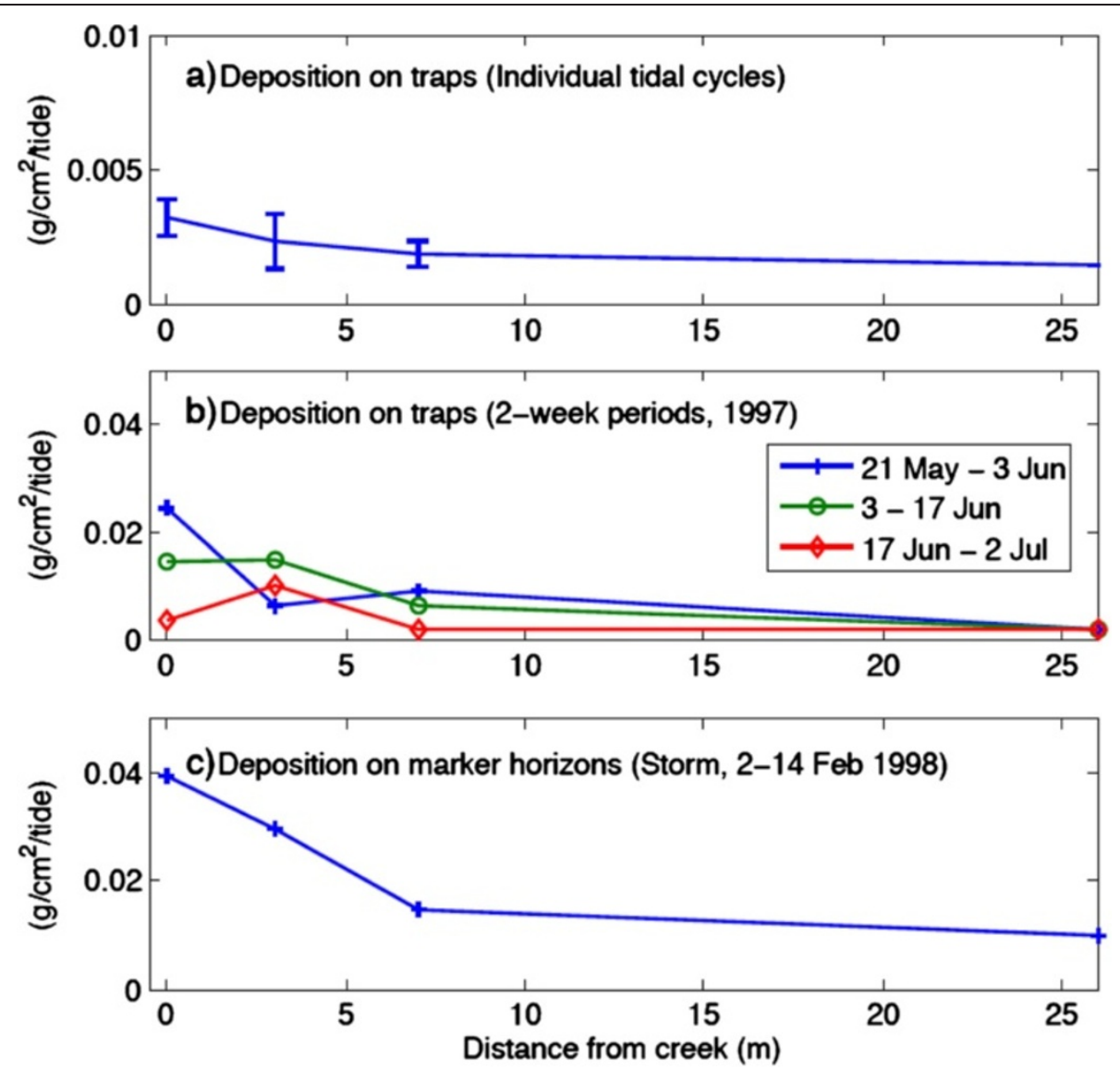

Figure 6 Sediment deposition measured along a transect extending from the edge of a tidal creek into the interior of the low marsh of a mainland marsh site on the Eastern Shore of Virginia. (a) Average deposition collected on sediment traps during individual tidal cycles; bars indicate standard error. (b) Deposition in sediment traps over three 2-week periods, divided by the number of tides flooding the marsh during those time intervals. Regular tidal flooding characterized the 17 Jun-2 Jul sampling period (12 tidal cycles). A small northeaster (2 tidal cycles out of 13) occurred during the 21 May-3 Jun sampling period, and a larger northeaster (9 tidal cycles out of 12) occurred during the 2-17 Jun sampling period. (c) Deposition above a marker horizon during a 2-week period that included a very large northeaster lasting from 4 to 9 Feb 1998 (nine tidal cycles). After Christiansen (1998).

estimated to contribute $27 \%$ of the annual deposition (Christiansen 1998).

Estimates of annual accretion based on short-term measurements of marsh deposition in the Virginia salt marsh site $\left(\sim 1 \mathrm{~g} \mathrm{~cm}^{-2}\right.$ year $^{-1}$, equivalent to about $1 \mathrm{~cm} /$ year assuming a bed porosity of about 0.65$)$ exceed rates based on longer-term measurements (e.g., SETs) and rates of sea-level rise, suggesting that the marsh surface is subject to erosion as well as deposition (Christiansen 1998). Because bed shear stresses due to tidal flows on the marsh are too low to erode sediment, it is likely that erosion occurs via another process. Studies in a South Carolina marsh (Mwamba and Torres 2002; Torres et al. 2003) showed that rainfall can mobilize large quantities of sediment on a saturated, exposed marsh surface and suggest that low-tide rainfall runoff driven by marsh topography may be the primary erosional process on intertidal salt marshes.

\section{Fluxes of organic material}

In the past years several studies have focused on the storage of organic carbon in salt marshes (Morris and Bowden 1986; Chmura et al. 2003; Hussein et al. 2004; Choi and Wang 2004). Mudd et al. (2009) presents a combined framework including both refractory and labile organic fractions, as well as root growth and decay. The model shows that the amount of carbon stored in salt marshes depends on the competition between mineral sediment deposition and organic-matter accumulation. Direct warming of the marsh due to climate change favors aboveground vegetation production, while sea level rise leads to more accommodation space, thus increasing rates of carbon burial (Kirwan and Mudd 2012).

However, little is known about tidal fluxes of dissolved and particulate carbon, which could dramatically affect the carbon budget of salt marshes. Tidal inundation 
brings estuarine organic matter to salt marshes via tidal creeks, and through biological, biogeochemical, and physical processes, the exported organic matter is altered quantitatively and qualitatively (Hemminga et al. 1992, 1993). Initial studies on lateral fluxes of organic carbon mainly focused on the volume of carbon exchanged between salt marsh and estuary. Teal (1962) assessed the energy budget of Sapelo Island salt marsh and found a $45 \%$ loss of production to the estuarine water. Although Teal's estimate was not based on direct flux measurements, ecologists have shown great interest in this hypothesis and many studies have been conducted to assess and develop this idea. Odum (1968) described the export of nutrients and organic detritus from salt marshes to coastal areas for supporting biotic activities as "outwelling" (Figure 7). During the four decades since 1970, more than 50 papers have been published developing this hypothesis. Among the studies available, only a few of them directly measured the flux of organic carbon transported by tidal water due to the difficulty of sampling water flow and constituent concentrations in tidal channels if the estuary is multi-channeled and over-flooded in spring tide (Dankers et al. 1984; Dame et al. 1986; Childers et al. 2000). In addition, in-situ continuous measurements of concentration were not available for many important constituents until field UV spectrometer and fluorometers were developed in recent years to measure nitrate, fluorescing dissolved organic matter (FDOM) colored dissolved organic matter (CDOM), chlorophyll, and turbidity. So far the largest data set available is from a long-term material flux measurement in Oyster Landing, North Inlet, South Carolina, USA (Gardner and Kjerfve 2006). The data set started in 1993 and has meteorological data at 30 min intervals as well as 13 water samples taken at $2 \mathrm{~h}$ intervals every 20 days over a period of 13 years. The finding that dissolved organic nitrogen (DON) and dissolved organic carbon
(DOC) are significantly exported is consistent with several previous flux studies at North Inlet.

There is general consensus that lateral fluxes of organic carbon from salt marshes to the coastal ocean are significant (Childers et al. 2000; Odum 2000; Valiela et al. 2000). Globally, export of organic carbon from salt marshes ranges from 27 to $1,052 \mathrm{~g} \mathrm{C} \mathrm{m}^{-2}$ year $^{-1}$ (Alongi 1998). Coastal geomorphology, geophysics, and hydrology are important determinants of organic matter exchange between coastal wetlands and estuaries (Bianchi 2007). In addition, from the perspective of stable isotope measurements and modeling, it has been shown that marsh DOC outwelling dominates particulate organic carbon (POC) outwelling (Eldridge and Cifuentes 2000). This conclusion is consistent with isotopic analysis suggesting that old, refractory organic carbon is dominant in riverine POC while salt marshes export more labile organic matter (Raymond and Bauer 2001; del Giorgio and Davis 2003).

Compared to quantitative studies of organic matter exchange between marsh and ocean, a small number of organic matter quality studies have been conducted so far. The quality of material flux could be interpreted as the identity (source) and functionality (fate) of the components within the pool of estuarine organic material. To identify the source of organic matter, researchers have used radioactive carbon and stable isotopic signatures of carbon, nitrogen, and sulfur (Peterson and Howarth 1987; Peterson et al. 1994; Raymond and Bauer 2001; Zhou et al. 2006), stoichiometry (Hopkinson and Vallino 2005; Lønborg et al. 2009), and biomarkers (Xu et al. 2006; Volkman et al. 2008). The studies of the fate of organic matter are based on biodegradability by using pyrolysis, gas chromatography-mass spectrometry (Hemminga et al. 1992, 1993; Klap et al. 1996), and laboratory bioassays with dark incubation (del Giorgio and Davis 2003; Moran and Covert 2003). Photodegradation studies also track another

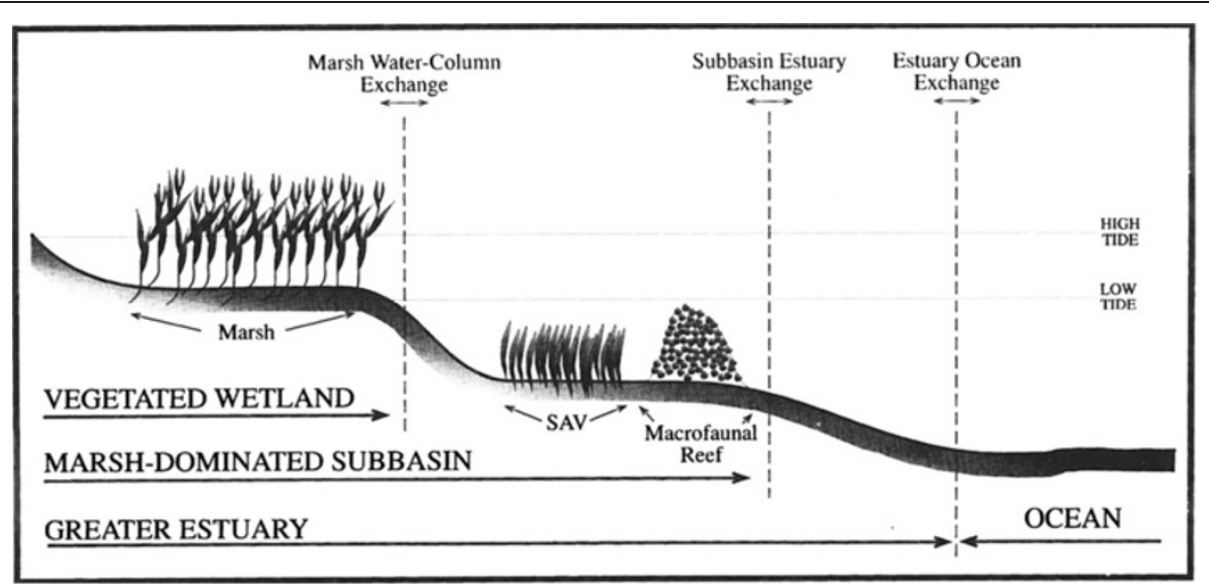

Figure 7 The outwelling concept, in which nested subsystems exchange material in an estuarine-coastal landscape (after Childers et al. 2000). 
major pathway of DOM consumption and transformation (1997; Del Vecchio and Blough 2002; Osburn et al. 2009). Spectroscopic techniques such as UV absorption and fluorescence detection [3D excitation-emission matrices (EEMs)] are now used both in source and fate studies (Goldberg 1990; Her et al. 2003; Alberts et al. 2004; Vignudelli et al. 2004; Jaffe et al. 2008).

A static model of aquatic organic matter mixing in salt marshes can be revealed by two-dimensional stable isotope plots of components in trophic levels, which are the organic matter providers (Figure 8). However, to understand the ecological processes at play in these dynamic coastal systems, we have to look into the quantity and quality of organic matter flux at different temporal and spatial scales. For example, analysis of 3D-EEM samples in a salt marsh creek in Plum Island Sound, Massachusetts, USA, show that at high tide more recently created DOM is available (likely microbial or algal; Figure 9 A-F). On the contrary at mid and low tide, when the tidal water is exported, old and refractory DOM is flushed away. A typical DOC flux pattern in the same tidal channel shows that the largest DOC flux happens during mid-tide. Therefore, a more significant signal of salt marsh organic matter should be present in the estuary at mid and low tidal levels.

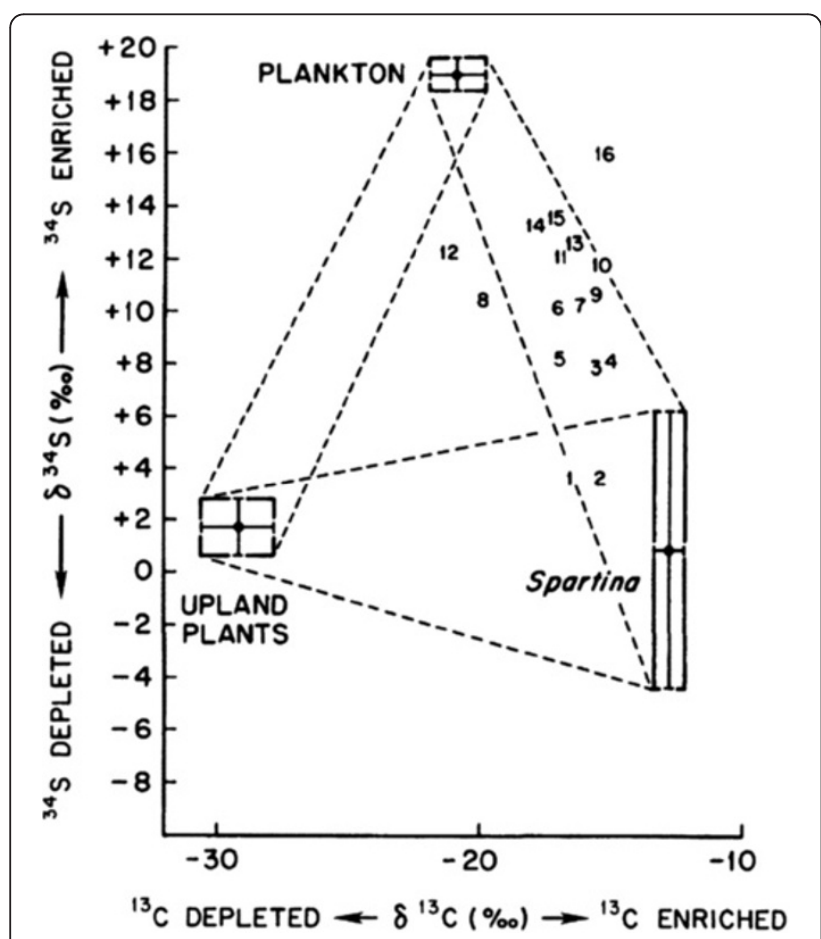

Figure 8 Sulfur isotopic ratio of marsh consumers as a function of stable isotopic ratio of carbon in the potential organic matter sources in Sapelo marshes. Different number indicates different species of consumers (after Peterson and Howarth 1987).
Two important environmental controls on the quantity and quality of salt marsh outwelling are light availability and extent of inundation (Hemminga et al. 1992, 1993; Kathilankal et al. 2008). The inundation of the salt marsh determines the extent of the surface that may interact and provide DOC to estuarine water, while light availability impacts both in-situ production by autotrophs and transformations through photo-oxidation. Soil decomposition could also change in terms of rates and pathways both because of diminished oxygen availability and because of the flushing of metabolic waste material into the water (Boon 2006). In the global theme of climate change, sea-level rise will increase the areal extent and frequency of inundations, and this could further affect the quantity and quality of organic matter mobilized in a tidal marsh estuary.

Lateral fluxes of organic matter are also an essential component of the short-term salt marsh carbon budget. Several studies have already determined the vertical carbon exchange between marshes and the atmosphere with eddy flux towers (Heinsch et al. 2004; Kathilankal et al. 2008; Guo et al. 2009, 2010; Polsenaere et al. 2012), but they were never coupled to lateral organic and inorganic carbon flux measurements with similar temporal and spatial resolution. Currently, field-ready FDOM fluorometers or UV spectrometers are a potential solution with a fine temporal resolution for in situ measurement of DOC, which represents $90 \%$ of primary production released from marshes to estuaries and to the sea (Eldridge and Cifuentes 2000). In addition, since in situ $\mathrm{pCO}_{2}$ and $\mathrm{pH}$ probes are available to measure DIC concentrations in tidal waters, it is now possible to close the carbon budget of a salt marsh.

\section{Fluxes of silica}

Salt marshes accumulate large amounts of biogenic silicon $[\mathrm{BSi}$, biogenically deposited hydrated amorphous $\mathrm{SiO}_{2} \cdot \mathrm{nH}_{2} \mathrm{O}$, present in plants, sponges, and diatoms, also referred to as amorphous $\mathrm{Si}$ (ASi); Struyf and Conley 2012] in sediments and vegetation. This can be recycled to dissolved $\mathrm{Si}\left[(\mathrm{DSi}), \mathrm{H}_{4} \mathrm{SiO}_{4-}\right.$, the dissolved form of $\mathrm{Si}$ available for biogenic uptake, also referred to as silicic acid], mainly in pore water and surface puddles. During ebb tide, this DSi is exported again to the estuary, where it can be an important source of Si for pelagic estuarine diatoms during times of $\mathrm{Si}$ limitation.

Most studies on Si cycling in tidal marshes have actually focused on tidal freshwater marshes (mostly in the Scheldt estuary; see Struyf and Conley 2009). However, in recent years, researchers have started investigating fluxes in salt marshes, and general mechanisms and processes as described below are similar (e.g., Querné et al. 2012; Vieillard et al. 2011) (Figure 10). 

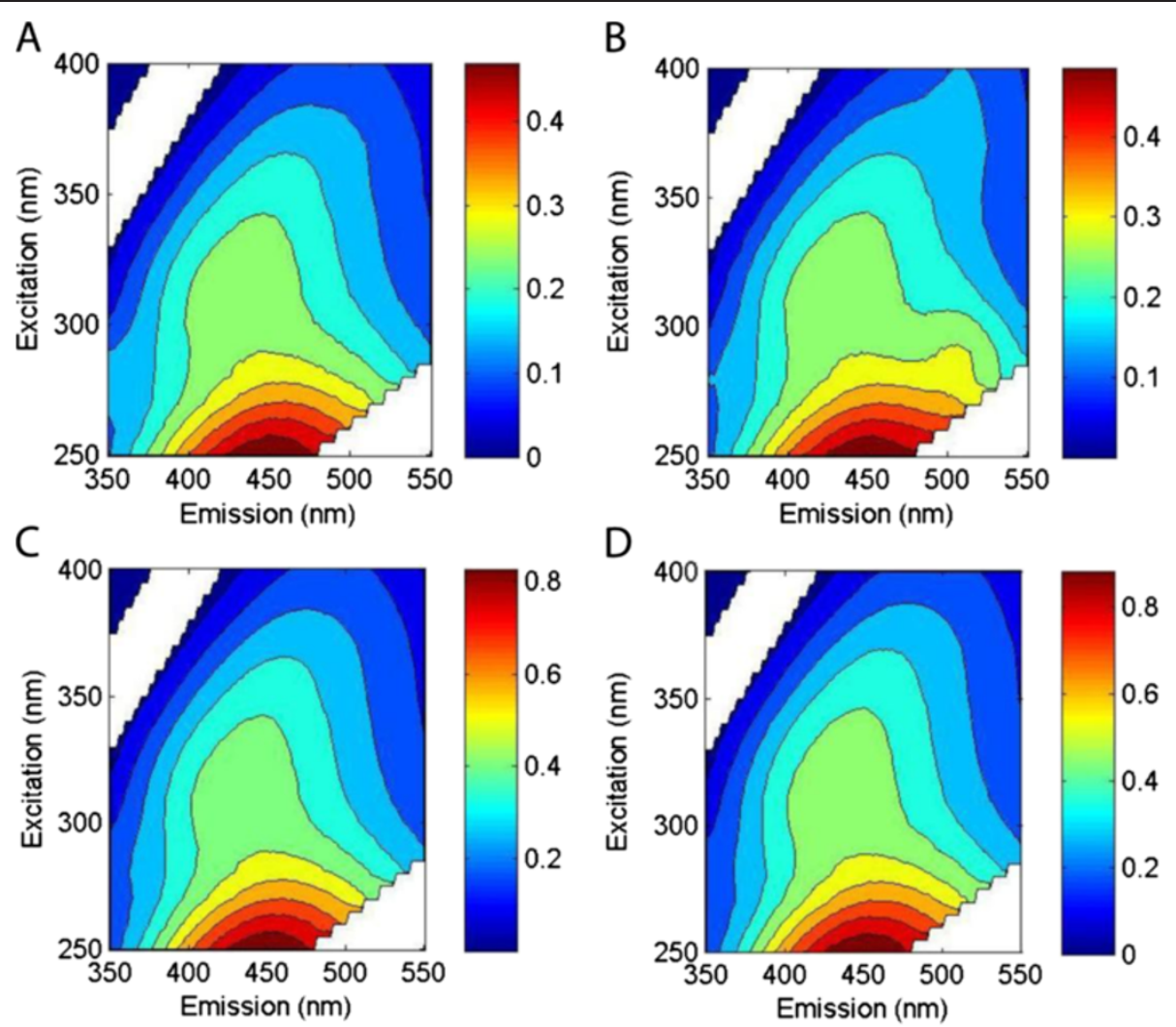

D
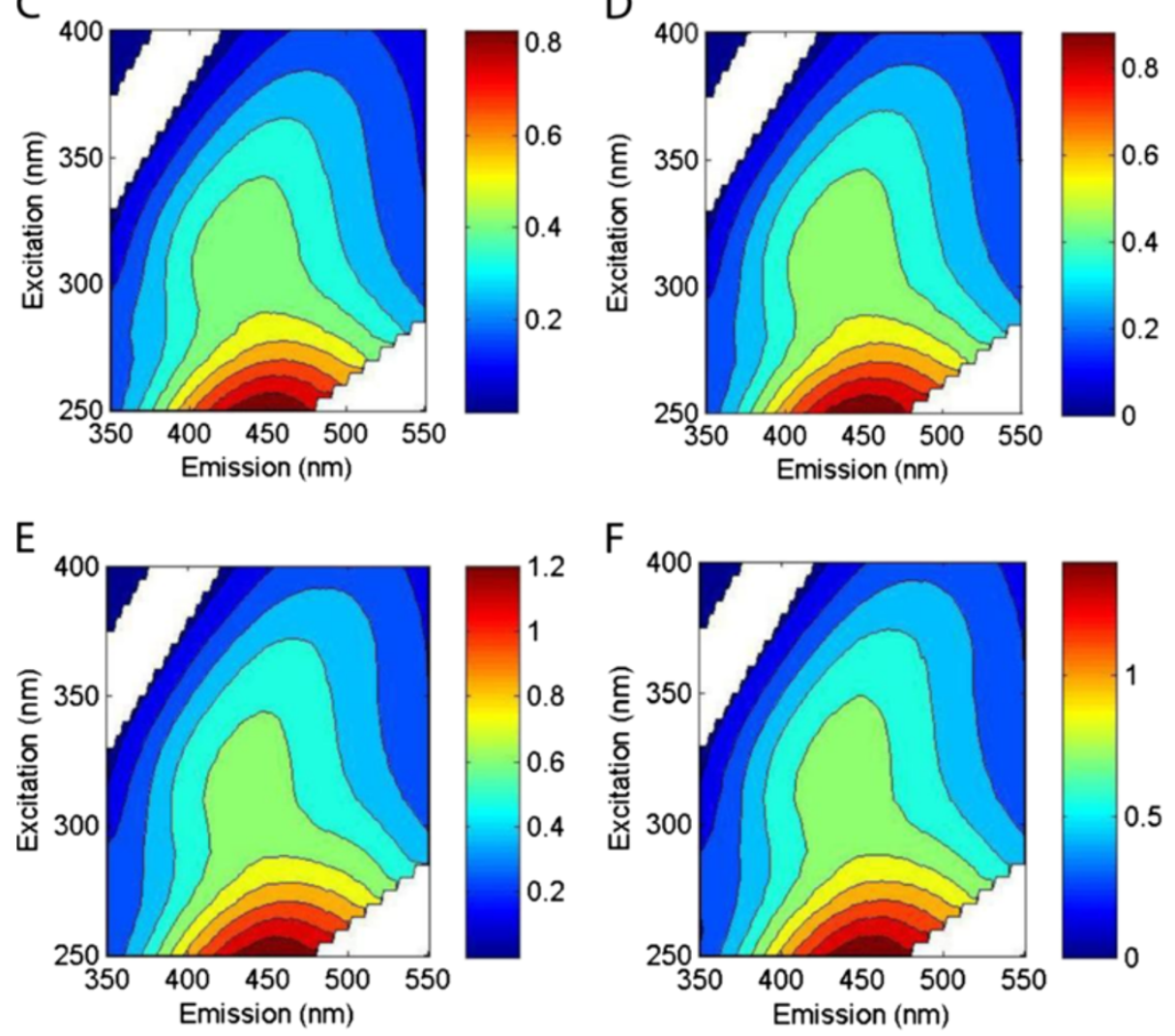

Figure 9 DOM quantity and quality dynamics of Plum Island Ecosystem (PIE) salt marsh. (A-F) 3D-EEM contours of water samples collected in a tidal creek during high, middle, and low tide on 1 and 31 Aug 2012, respectively.

Where does the build-up of BSi originate from? As discussed in the previous section, marshes receive large amounts of suspended matter during tidal flooding. Together with suspended matter, BSi is imported (e.g., Struyf et al. 2005a). Few studies have actually investigated whether this BSi mainly originates from pelagic diatom production within nearby coastal or estuarine waters or from terrestrial inputs of BSi (e.g., plant Si particles called phytoliths) through rivers discharging into the estuary. This distinction probably depends on the season: in spring and summer, estuarine production of diatoms is high, as reflected in high BSi concentrations in coastal water, coinciding with low DSi due to diatom uptake (e.g., Struyf et al. 2006; Carbonnel et al. 2009). In winter, suspended solids concentrations are often higher within estuaries (e.g., Fettweis et al. 1998; Lesourd et al. 2003), but BSi content of the suspended matter (SPM) is low (Struyf et al. 2007a), which suggests that BSi mainly originates from external terrestrial inputs (e.g., soil runoff), reflected in high concurrent DSi in the estuary (no diatom uptake). In a study in the Scheldt estuary, it was found that absolute import of $\mathrm{BSi}$ into marshes is 


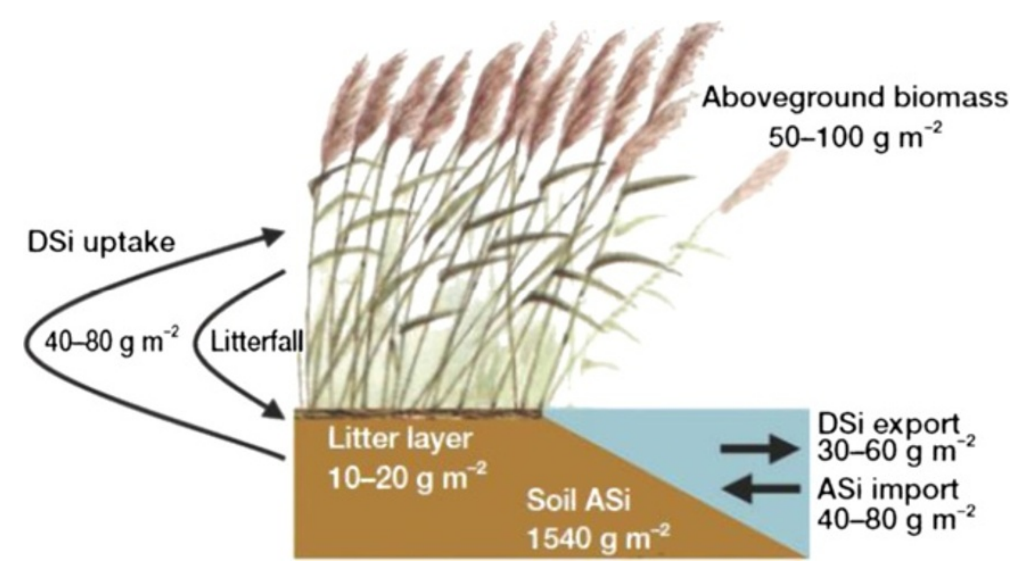

Figure 10 Stocks and yearly fluxes of DSi and ASi within a Belgian freshwater marsh. Sediment stocks are for the upper $30 \mathrm{~cm}$. Litter fall and DSi uptake by vegetation equal each other on an annual time scale (from Struyf and Conley 2009).

highest in winter, as the higher import of SPM offsets the lower BSi content in the SPM (Struyf et al. 2007a).

Tidal import of BSi is not the only source for BSi accumulation in marshes. A second, very scarcely studied factor is the autochthonous production of diatoms in the marshes. Hackney et al. (2000) indicated that high diatom production in tidal marshes and the food web dependent on this production could actually be important contributors to estuarine production (as earlier suggested by Sullivan and Moncreiff 1990). Macrophytes are another factor in autochthonous production of BSi; aquatic and wetland plants can contain significant amounts of BSi (Schoelynck et al. 2010). In freshwater marshes, Phragmites australis is particularly rich in BSi (Struyf et al. 2007b; up to 5\% of the dry biomass in dead reed culms is BSi in saltwater and mesohaline marshes, the dry biomass of Spartina alterniflora and Juncus roemerianus contains up to $\pm 0.5 \%$ of $\mathrm{BSi}$ (Norris and Hackney 1999; Querné et al. 2012). The relative contribution of autochthonous production vs. tidal import to the total BSi stock in tidal marshes certainly warrants further investigation.

The high BSi import and autochtonous BSi production in tidal marshes result in high concentrations of DSi in marsh pore water and tidal pools $(100-600 \mu \mathrm{M}$; e.g., Norris and Hackney 1999; Jacobs et al. 2008; Struyf et al. 2005b; Querné et al. 2012) Tidal pools can show a strong decrease in DSi due to diatom production. Plants could have a similar effect on pore water DSi concentrations, but the limited available studies do not confirm this hypothesis (Querné et al. 2012). Due to its high solubility in comparison to mineral silicates, sediment and soil BSi can exert strong control on DSi concentrations in wetland pore water (e.g., Struyf et al. 2009). Concentrations of DSi in marsh water are two- to fivefold higher in comparison to maximum concentrations observed in the upper reaches of estuaries: the average riverine DSi concentration is $100 \mu \mathrm{M}$ (Conley 1997), but higher concentrations (up to $250 \mu \mathrm{M}$ ) have been observed in the freshwater tidal reaches of the Scheldt estuary (Belgium) (Carbonnel et al. 2009). These are, however, maximum concentrations: in summer, diatom production can reduce DSi concentrations, even in the upstream tidal reaches, to concentrations near $5 \mu \mathrm{M}$ (e.g., Cox et al. 2009; Carbonnel et al. 2009). In general, estuarine DSi concentrations also decrease with increasing salinity, due to conservative mixing with seawater and diatom uptake, reaching concentrations below $20 \mu \mathrm{M}$ at higher salinity (e.g., Van Damme et al. 2005). There is thus a strong enrichment of both easily soluble BSi and DSi in tidal marshes compared to adjacent estuarine and coastal waters. As a result, ebb water flowing out of tidal marshes is enriched with DSi compared to inflowing water, especially in the seepage water (i.e., soil pore water flowing out of the tidal marsh soil when estuarine tidal height has dropped below marsh elevation) (e.g., Struyf et al. 2006; Vieillard et al. 2011) (Figure 11). Especially in summer months, when concentrations of DSi in estuaries are reduced due to diatom uptake, and coastal DSi concentrations are minimal, this DSi export from tidal marshes could be an important factor in supporting estuarine and coastal diatom production (Figure 12).

Mass-balance studies show that the magnitude of observed export fluxes of DSi is similar to modeled and experimental results for $\mathrm{BSi}$ recycling fluxes (Struyf et al. 2007a, b). There is thus a strong indication that export of $\mathrm{Si}$ from the marsh to the estuary is a biologically controlled mechanism, despite large amounts of mineral Si (e.g., clays) that are imported along with suspended matter into the marsh at flood tide. This is because mineral $\mathrm{Si}$ is orders of magnitude less soluble than BSi. Finally, the large accumulation of BSi in salt marshes points to a strong role of biology in the Si cycle. 


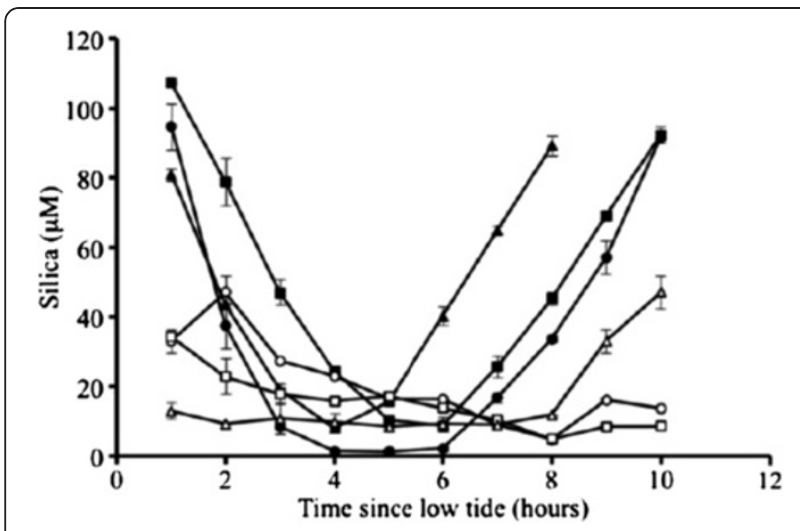

Figure 11 Average dissolved (closed symbols) and biogenic (open symbols) silica concentrations over the average of three summer tidal cycles. Circles, squares, and triangles represent neap, mid, and spring tidal ranges, respectively. Hours one and ten are low tide and represent the strongest marsh export water signal (and highest DSi). Error bars are standard errors (from Vieillard et al. 2011).

Marshes therefore potentially increase the resilience of coastal waters to dissolved Si limitation and associated phytoplankton shifts to non-diatom communities. N-P-Si ratios are important in controlling estuarine and coastal phytoplankton composition; increased inputs of $\mathrm{N}$ and $\mathrm{P}$ due to human activities have led to shifts from diatomdominated communities (which essentially need DSi) to a prevalence of other phytoplankton species (e.g., Smayda 1997) that are less available to higher trophic levels. In comparison to studies on carbon, nitrogen, and phosphorus, results on silicon cycling in tidal marshes are still

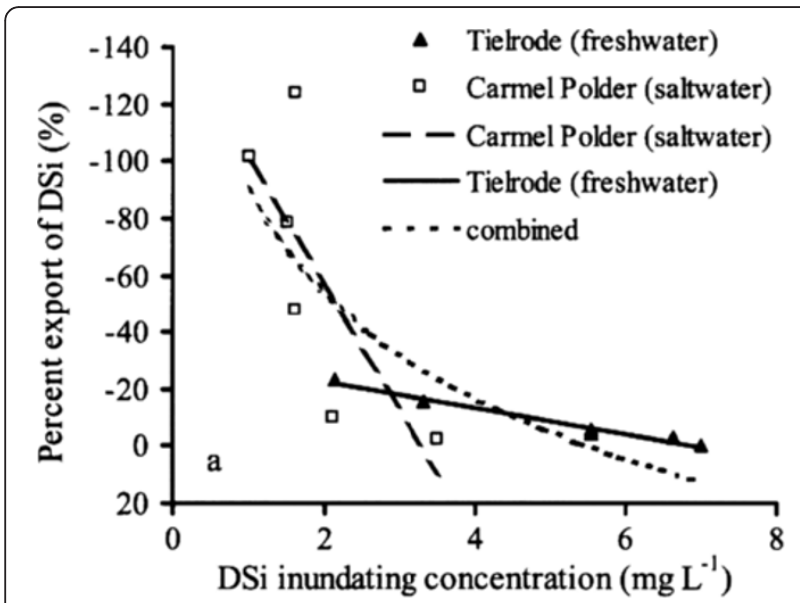

Figure 12 Percent export of DSi (extra export relative to total imported DSi during inflow) from the Tielrode (freshwater, Belgium) and Carmel Polder (saltwater, France) wetlands in relation to the inundating DSi concentration (linear regressions for Tielrode: $F_{1,4}=144, r^{2}=0.97, p<0.001$; and Carmel Polder $\left.F_{1,4}=5.61, r^{2}=0.58, p=0.08\right)$. Combined data sets result in a logarithmic relation $\left(F_{1,10}=18.2, r^{2}=0.64, p<0.002\right)$; from Struyf et al. (2006) limited. The general importance of BSi accumulation and DSi delivery by tidal marshes has been confirmed in a growing number of studies (e.g., Struyf et al. 2005a, 2006; Jacobs et al. 2008; Vieillard et al. 2011).

\section{Conclusions}

Tidal oscillations systematically flood salt marshes transporting water, sediments, organic matter, and biogeochemical elements such as silica. To measure water fluxes in a salt marsh drained by tidal channels, three different approaches can be adopted, depending on what hydrodynamic quantities need to be computed:

- The tidal prism (Equation 1) provides an estimate of the total volume of water exchanged by a marsh in a tidal cycle.

- If the value of the instantaneous discharge is needed, the static model of Boon (Equation 2) is simple and adequate.

- If we seek the flow velocity or the distribution of residence times, the use of the TIGER model is recommended (Equation 3).

These simplified approaches are particularly suitable for the study of fluxes of biogeochemical compounds in salt marshes and could be easily adopted by researchers working in this area.

Sediment fluxes to and from the marsh strongly depend on sediment resuspension by waves and currents. Recent results show that:

- During flood the input of sediment to the marsh depends on resuspension of sediments in adjacent areas by wind waves and tidal currents.

- During ebb the export of sediments is strongly affected by the magnitude of water velocity in the channels draining the marsh.

- Storm surges import large volumes of sediment to the marsh, but they also export a comparable amount during the subsequent ebb due to the high velocities in the channels and related bottom shear stresses.

- Moderate storm conditions with limited surges maximize the sediment import to the marsh.

Knowledge of internal marsh processes and mechanisms affecting both biogenic silicon and organic matter accumulation and turnover is scarce. It is likely that more and more measurement methods will be available in the future to allow us to investigate ecological processes at a finer temporal, spatial, and chemical resolution and at broader scale.

Regarding lateral flux studies of salt marsh organic matter, the following key topics for future studies are suggested: 
- Long-term data sets with fine temporal resolution of lateral organic and inorganic matter exchange should be coupled to eddy flux tower data sets to close the carbon budget in salt marshes.

- Quality of organic matter should also be measured in tidal fluxes, together with its interactions at different trophic levels.

- Linkages between organic matter fluxes and salt marsh physical and physiological processes should be established.

- Recent studies on fluxes of organic matter have focused more on the entire estuarine system, including fluxes from the ocean and nearby fluvial watersheds. More research is clearly needed to determine the mechanisms controlling fluxes of organic matter within the marsh system, for example from the marsh platform to the tidal channels and vice versa.

To move knowledge beyond the general pattern of BSi accumulation and DSi delivery, several key topics can be defined:

- How does the balance between BSi accumulation and DSi delivery change along gradients of marsh age, salinity, and seasons? Scarce studies so far have indicated net accumulation in tidal freshwater marshes in the Scheldt estuary over a decadal timescale (burial of about $40 \%$ of imported BSi without dissolution to DSi). This balance is crucial to understanding the long-term role of tidal marshes in coastal Si cycling: net annual accumulation of BSi could be equally as important as (or even more important than) seasonal delivery of DSi.

- What is the importance of Si-rich vegetation and diatom production in tidal marshes for coastal food webs?

- What processes potentially impact BSi accumulation and DSi recycling in tidal marshes through their impact on sediment accumulation and vegetation and diatom growth, such as grazing management, sea level rise, invasive species, and hydroengineering?

\section{Competing interests}

The authors declare that they have no competing interests.

\section{Authors' contributions}

SF wrote the paragraph on Fluxes of Water, PW and SW wrote the paragraph on Fluxes of Sediments, YZ and PR wrote the paragraph on Fluxes of Organic Material, ES and ST wrote the paragraph on Fluxes of Silica. All authors read and approved the final manuscript.

\section{Acknowledgments}

SF was supported by NSF award OCE-0924287 and DEB-0621014 (VCR-LTER program).

\section{Author details}

'Department of Earth and Environment, Boston University, Boston, MA, USA. ${ }^{2}$ Department of Environmental Sciences, University of Virginia, Charlottesville, VA, USA. ${ }^{3}$ Department of Biology, Ecosystem Management research group, University of Antwerpen, Antwerpen, Belgium. ${ }^{4}$ School of Forestry \& Environmental Studies, Yale University, New Haven, CT, USA.

Received: 27 September 2012 Accepted: 14 December 2012 Published: 27 February 2013

\section{References}

Alberts JJ, Takacs M, Shalles M (2004) Ultraviolet-visible and fluorescence spectral evidence of natural organic matter (NOM) changes along an estuarine salinity gradient. Estuaries 27(2):296-310

Alongi D (1998) Coastal ecosystem processes. CRC Press, Boca Raton, p 448

Bayliss-Smith TP, Healey R, Lailey R, Spencer T, Stoddart DR (1978) Tidal flows in salt marsh creeks. Estuarine Coastal Mar Sci 9:235-255

Bianchi TS (2007) Biogeochemistry of estuaries. Oxford University Press, New York

Boon JD (1975) Tidal discharge asymmetry in a salt marsh drainage system. Limnol Oceanogr 20:71-80

Boon PI (2006) Biogeochemistry and bacterial ecology of hydrologically dynamic wetlands. In: Batzer DP, Sharitz RR (ed) Ecology of freshwater and estuarine wetlands. University of California Press, Berkeley, p 568

Cahoon DR (2006) A review of major storm impacts on coastal wetland elevations. Estuaries Coasts 29:889-898

Cai WJ (2011) Estuarine and coastal ocean carbon paradox: CO2 sinks or sites of terrestrial carbon incineration? Annu Rev Mar Sci 3(3):123-145

Carbonnel V, Lionard M, Muylaert K, Chou L (2009) Dynamics of dissolved and biogenic silica in the freshwater reaches of a macrotidal estuary (The Scheldt, Belgium). Biogeochemistry 96:49-72

Carniello L, Defina A, Fagherazzi S, D'Alpaos L (2005) A combined wind wavetidal model for the Venice lagoon, Italy. J Geophys Res 110(F4):F04007. doi:10.1029/2004JF000232

Childers DL, Day JW, Mckeller HN (2000) Twenty more years of marsh and estuarine flux studies: revisiting Nixon (1980). In: Weinsteiner MP, Kreeger DA (ed) Concepts and controversies in tidal marsh ecology, 5. Springer, New York, pp 391-423

Chmura GL, Anisfeld SC, Cahoon DR, Lynch JC (2003) Global carbon sequestration in tidal, saline wetland soils. Global Biogeochem Cycles 17(4):1111

Choi YH, Wang Y (2004) Dynamics of carbon sequestration in a coastal wetland using radiocarbon measurements. Global Biogeochem Cycles 18(4):GB4016. doi:10.1029/2004GB002261

Christiansen T (1998) Sediment deposition on a tidal salt marsh. Ph.D. Dissertation. University of Virginia, Charlottesville, p 114

Christiansen T, Wiberg PL, Milligan TG (2000) Flow and sediment transport on a tidal salt marsh surface. Estuarine Coastal Shelf Sci 50:315-331

Church TM (1986) Biogeochemical factors influencing the residence time of microconstituents in a large tidal estuary, Delaware Bay. Mar Chem 18(2-4):393-406

Conley DJ (1997) Riverine contribution of biogenic silica to the oceanic silica budget. Limnol Oceanogr 42:774-777

Cox T, Maris T, Soetaert K, Conley DJ, Van Damme S, Meire P, Middelburg JJ, Vos M, Struyf E (2009) A macro-tidal freshwater ecosystem recovering from hyper-eutrophication: the Schelde case study. Biogeosciences 6:2935-2948

Crump BC, Hopkinson CS, Sogin ML, Hobbie JE (2004) Microbial biogeography along an estuarine salinity gradient: combined influences of bacterial growth and residence time. Appl Environ Microbiol 70(3):1494-1505

D'Alpaos A, Lanzoni S, Marani M, Fagherazzi S, Rinaldo A (2005) Tidal network ontogeny: channel initiation and early development. J Geophys Res-Earth Surface 110:F02001. doi:10.1029/2004JF000182

D'Alpaos A, Lanzoni S, Mudd SM, Fagherazzi S (2006) Modeling the influence of hydroperiod and vegetation on the cross-sectional formation of tidal channels. Estuarine Coastal Shelf Sci 69(3-4):311-324

D'Alpaos A, Lanzoni S, Marani M, Rinaldo A (2007) Landscape evolution in tidal embayments: modeling the interplay of erosion, sedimentation, and vegetation dynamics. J Geophys Res 112:F01008. doi:10.1029/2006JF000537

D'Alpaos A, Lanzoni S, Marani M, Rinaldo A (2010) On the tidal prism-channel area relations. J Geophys Res 115:F01003. doi:10.1029/2008JF001243

Dame R, Chrzanowski T, et al. (1986) The outwelling hypothesis and North Inlet, South-Carolina. Mar Ecol Prog Ser 33(3):217-229 
Dankers N, Binsbergen M, Zegers K, Laane R, Vanderloeff MR (1984) Transportation of water, particulate and dissolved organic and inorganic matter between a salt-marsh and the Ems-Dollard Estuary, the Netherlands. Estuarine Coastal Shelf Sci 19(2):143-165

Davidson-Arnott RGD, Van Proosdij D, Ollerhead J, Schostak L (2002) Hydrodynamics and sedimentation in salt marshes: examples from a macrotidal marsh, Bay of Fundy. Geomorphology 48:209-231

del Giorgio PA, Davis J (2003) Patterns of dissolved organic matter lability and consumption across aquatic ecosystems. In: Findlay SEG, Sinsabaugh RL (ed) Aquatic ecosystems: interactivity of dissolved organic matter. Academic Press, San Diego, pp 399-424

Del Vecchio R, Blough NV (2002) Photobleaching of chromophoric dissolved organic matter in natural waters: kinetics and modeling. Mar Chem 78(4):231-253

Duarte CM, Middelburg JJ, Caraco N (2005) Major role of marine vegetation on the oceanic carbon cycle. Biogeosciences 2(1):1-8

Eldridge PM, Cifuentes LA (2000) A stable isotope model approach to estimating the contribution of organic matter from marshes to estuaries. In: Weinsteiner MP, Kreeger DA (ed) Concepts and controversies in tidal marsh ecology. Springer, New York, pp 495-513

Fagherazzi S, Furbish DJ (2001) On the shape and widening of salt marsh creeks. J Geophys Res 106(C1):991-1005

Fagherazzi S, Priestas AM (2010) Sediments and water fluxes in a muddy coastline: interplay between waves and tidal channel hydrodynamics. Earth Surf Process Landforms 35(3):284-293

Fagherazzi S, Sun T (2004) A stochastic model for the formation of channel networks in tidal marshes. Geophys Res Lett 31:L21503. doi:10.1029/ 2004GL020965

Fagherazzi S, Palermo C, Rulli MC, Carniello L, Defina A (2007) Wind waves in shallow microtidal basins and the dynamic equilibrium of tidal flats. J Geophys Res 112:F02024. doi:10.1029/2006JF000572

Fagherazzi S, Hannion M, D'Odorico P (2008) Geomorphic structure of tidal hydrodynamics in salt marsh creeks. Water Resour Res 44:W02419. doi:10.1029/2007WR006289

Fagherazzi S, Mariotti G, Porter JH, McGlathery KJ, Wiberg PL (2010) Wave energy asymmetry in shallow bays. Geophys Res Lett 37:L24601

Fagherazzi S, Kirwan ML, Mudd SM, Guntenspergen GR, Temmerman S, D'Alpaos A, van de Koppel J, Rybczyk JM, Reyes E, Craft C, Clough J (2012) Numerical models of salt marsh evolution: ecological and climatic factors. Rev Geophys 50(1):. doi:10.1029/2011RG000359

Fettweis M, Sas M, Monbaliu J (1998) Seasonal, neap-spring and tidal variation of cohesive sediment concentration in the Scheldt Estuary, Belgium. Estuarine Coastal Shelf Sci 47:21-36

French JR, Stoddart DR (1992) Hydrodynamics of salt-marsh creek systems: implications for marsh morphological development and material exchange. Earth Surf Processes Landforms 17(3):235-252

French JR, Spencer T, Murray AL, Arnold NS (1995) Geostatistical analysis of sediment deposition in two small tidal wetlands, Norfolk, United Kingdom. J Coastal Res 11:308-321

Friedrichs CT, Aubrey DG (1988) Non-linear tidal distorsion in shallow well-mixed estuaries: a synthesis. Estuarine Coastal Shelf Sci 27:521-545

Gardner LR (2005) Role of geomorphic and hydraulic parameters in governing pore water seepage from salt marsh sediments. Water Resour Res 41: W07010. doi:10.1029/2004WR003671

Gardner LR, Kjerfve B (2006) Tidal fluxes of nutrients and suspended sediments at the North Inlet - Winyah Bay National Estuarine Research Reserve. Estuarine Coastal Shelf Sci 70(4):682-692

Goldberg MC (1990) Determination of the transport and change in composition of fluorescent materials in hydrologic systems by use of Eem-spectroscopy. Abstr Pap Am Chem Soc 199:24-Envr

Guo HQ, Noormets A, et al. (2009) Tidal effects on net ecosystem exchange of carbon in an estuarine wetland. Agr Forest Meteorol 149(11):1820-1828

Guo HQ, Zhao B, Chen JQ, Yan YE, Li B, Chen JK (2010) Seasonal changes of energy fluxes in an estuarine wetland of Shanghai, China. Chin Geogr Sci 20(1):23-29

Hackney CT, Cahoon LB, Prestos C, Norris A (2000) Silicon is the link between tidal marshes and estuarine fisheries: a new paradigm. In: Weinstein MP, Kreeger DA (ed) Concepts and controversies in tidal marsh ecology. Kluwer, Amsterdam, pp 543-552

Healey RG, Pye K, Stoddart DR, Bayliss-Smith TP (1981) Velocity variations in salt marsh creeks, Norfolk, England. Estuarine Coastal Shelf Sci 13:535-555
Heinsch FA, Heilman JL, et al. (2004) Carbon dioxide exchange in a high marsh on the Texas Gulf Coast: effects of freshwater availability. Agr Forest Meteorol 125(1-2):159-172

Hemminga MA, Klap VA, Vansoelen J, Deleeuw J, Boon JJ (1992) Shifts in Seston characteristics after inundation of a European coastal salt-marsh. Limno Oceanogr 37(7):1559-1564

Hemminga MA, Klap VA, Vansoelen J, Boon JJ (1993) Effect of salt-marsh inundation on estuarine particulate organic-matter characteristics. Mar Ecol Prog Ser 99(1-2):153-161

Her N, Amy G, McKnight D, Sohn J, Yoon YM (2003) Characterization of DOM as a function of MW by fluorescence EEM and HPLC-SEC using UVA, DOC, and fluorescence detection. Water Res 37(17):4295-4303

Hopkinson CS, Vallino JJ (2005) Efficient export of carbon to the deep ocean through dissolved organic matter. Nature 433(7022):142-145

Hopkinson CS, Cai WJ, Hu XP (2012) Carbon sequestration in wetland dominated coastal systems - a global sink of rapidly diminishing magnitude. Curr Opin Environ Sustain 4(2):186-194

Howes BL, Goehringer DD (1994) Porewater drainage and dissolved organic carbon and nutrient losses through the intertidal creek banks of a New England salt marsh. Mar Ecol Prog Ser 114:289-301

Hussein AH, Rabenhorst MC, Tucker ML (2004) Modeling of carbon sequestration in coastal marsh soils. Soil Sci Soc Am J 68(5):1786-1795

Jacobs S, Struyf E, Maris T, Meire P (2008) Spatio-temporal aspects of silica buffering in restored tidal marshes. Estuarine Coastal Shelf Sci 80:42-52

Jaffe R, McKnight D, et al. (2008) Spatial and temporal variations in DOM composition in ecosystems: the importance of long-term monitoring of optical properties. J Geophys Res-Biogeosciences 113(G4):G04032

Kathilankal JC, Mozdzer TJ, Fuentes JD, D'Odorico P, McGlathery KJ, Zieman JC (2008) Tidal influences on carbon assimilation by a salt marsh. Environ Res Lett 3(4):044010

Kirwan ML, Mudd SM (2012) Response of salt-marsh carbon accumulation to climate change. Nature 489(7417):550. doi:10.1038/nature11440

Kirwan ML, Guntenspergen GR, D'Alpaos A, Morris JT, Mudd SM, Temmerman S (2010) Limits on the adaptability of coastal marshes to rising sea level. Geophysical Res Lett 37:L23401. doi:10.1029/2010GL045489

Klap VA, Boon JJ, Hemminga MA, vanSoelen J (1996) Assessment of the molecular composition of particulate organic matter exchanged between the Saeftinghe salt marsh (southwestern Netherlands) and the adjacent water system. Mar Chem 54(3-4):221-243

Lawrence DSL, Allen JRL, Havelock GM (2004) Salt marsh morphodynamics: an investigation of tidal flows and marsh channel equilibrium. J Coastal Res 20(1):301-316

Lawson SE, Wiberg PL, McGlathery KJ, Fugate DC (2007) Wind-driven sediment suspension controls light availability in a shallow coastal lagoon. Estuaries Coasts 30:102-112

Leonard LA (1997) Controls on sediment transport and deposition in an incised mainland marsh basin, southeastern North Carolina. Wetlands 17:263-274

Leonard LA, Luther ME (1995) Flow hydrodynamics in tidal marsh canopies. Limnol Oceanogr 40:1474-1484

Lesourd S, Lesueur P, Brun-Cottan JC, Garnaud S, Poupinet N (2003) Seasonal variations in the characteristics of superficial sediments in a macrotidal estuary (the Seine inlet, France). Estuarine Coastal Shelf Sci 58:3-16

Lønborg C, Álvarez-Salgado XA, Davidson K, Miller AEJ (2009) Production of bioavailable and refractory dissolved organic matter by coastal heterotrophic microbial populations. Estuarine Coastal Shelf Sci 82 (4):682-688

Marani M, Belluco E, D’Alpaos A, Defina A, Lanzoni S, Rinaldo A (2003) On the drainage density of tidal networks. Water Resour Res 39(2):1040. doi:10.1029/2001WR001051

Mariotti G, Fagherazzi S (2010) A numerical model for the coupled long-term evolution of salt marshes and tidal flats. J Geophys Res 115:F01004. doi:10.1029/2009JF001326

McLeod E, Chmura GL, et al. (2011) A blueprint for blue carbon: toward an improved understanding of the role of vegetated coastal habitats in sequestering CO2. Front Ecol Environ 9(10):552-560

Middelburg JJ, Nieuwenhuize J, Lubberts RK, van de Plassche O (1997) Organic carbon isotope systematics of coastal marshes. Estuarine Coastal Shelf Sci 45(5):681-687

Möller I, Spencer T, French JR, Leggett DJ, Dixon M (1999) Wave transformation over salt marshes: a field and numerical modelling 
study from North Norfolk, England. Estuarine Coastal Shelf Sci 49 (3):411-426

Moran MA, Covert J (2003) Photochemically mediated linkages between dissolved organic matter and bacterioplankton. In: Findlay SEG, Sinsabaugh RL (ed) Aquatic ecosystems: interactivity of dissolved organic matter. Academic Press, San Diego

Morris JT, Bowden WB (1986) A mechanistic, numerical model of sedimentation, mineralization, and decomposition for marsh sediments. Soil Sci Soc Am J 50(1):96-105

Morris DP, Hargreaves BR (1997) The role of photochemical degradation of dissolved organic carbon in regulating the UV transparency of three lakes on the Pocono Plateau. Limnol Oceanogr 42(2):239-249

Morris JT, Sundareshwar PV, Nietch CT, Kjerfve B, Cahoon DR (2002) Responses of coastal wetlands to rising sea level. Ecology 83:2869-2877

Moskalski SM, Sommerfield CK (2012) Suspended sediment deposition and trapping efficiency in a Delaware salt marsh. Geomorphology 139-140:195-204

Mudd SM, Fagherazzi S, Morris JT, Furbish DJ (2004) Flow, sedimentation, and biomass production on a vegetated salt marsh in South Carolina: toward a predictive model of marsh morphologic and ecologic evolution. In: Fagherazzi S, Marani M, Blum LK (ed) The ecogeomorphology of tidal marshes. Coastal and Estuarine Studies, vol. 59. AGU, Washington DC, pp 165-187

Mudd SM, Howell SM, Morris JT (2009) Impact of dynamic feedbacks between sedimentation, sea-level rise, and biomass production on near surface marsh stratigraphy and carbon accumulation. Estuarine Coastal Shelf Sci 82(3):377-389

Mwamba MJ, Torres R (2002) Rainfall effects on marsh sediment redistribution, North Inlet, South Carolina. Mar Geol 189:267-287

Myrick RM, Leopold LB (1963) Hydraulic geometry of a small tidal estuary. US Geol Surv Prof Pap 422-B. US GPO, Washington DC

Nepf HM (1999) Drag, turbulence, and diffusion in flow through emergent vegetation. Water Resour Res 35(2):479. doi:10.1029/1998WR900069

Norris AR, Hackney CT (1999) Silica content of a mesohaline tidal marsh in North Carolina. Estuarine Coastal Shelf Sci 49:597-605

Odum EP (1968) A research challenge: evaluating the productivity of coastal and estuarine water. Proceeding of Second Sea Grant Conference. University of Rhode Island, Kingston

Odum EP (2000) Tidal marshes as outwelling/pulsing systems. In: Weinsteiner MP, Kreeger DA (ed) Concepts and controversies in tidal marsh wcology. Springer, New York, pp 3-7

Osburn CL, Retamal L, Vincent WF (2009) Photoreactivity of chromophoric dissolved organic matter transported by the Mackenzie River to the Beaufort Sea. Mar Chem 115(1-2):10-20

Peterson BJ, Howarth RW (1987) Sulfur, carbon, and nitrogen isotopes used to trace organic-matter flow in the salt-marsh estuaries of Sapelo Island, Georgia. Limnol Oceanogr 32(6):1195-1213

Peterson B, Fry B, Hullar M, Saupe S, Wright R (1994) The distribution and stable carbon isotopic composition of dissolved organic carbon in estuaries. Estuaries 17(1B):111-121

Pethick JS (1980) Velocities, surges and asymmetry in tidal channels. Estuarine Coastal Mar Sci 11:331-345

Polsenaere P, Lamaud E, et al. (2012) Spatial and temporal CO2 exchanges measured by eddy covariance over a temperate intertidal flat and their relationships to net ecosystem production. Biogeosciences 9(1):249-268

Querné J, Ragueneau O, Poupart N (2012) In situ biogenic silica variations in the invasive salt marsh plant, Spartina alterniflora: a possible link with environmental stress. Plant Soil 352:157-171

Raymond PA, Bauer JE (2001) Use of C-14 and C-13 natural abundances for evaluating riverine, estuarine, and coastal DOC and POC sources and cycling: a review and synthesis. Org Geochem 32(4):469-485

Reed DJ (1989) Patterns of sediment deposition in subsiding salt marshes, Terrebonne Bay, Louisiana: the role of winter storms. Estuaries 12 (4):222-227

Reed DJ, Spencer T, Murray AL, French JR, Leonard L (1999) Marsh surface sediment deposition and the role of tidal creeks: implications for created and managed coastal marshes. J Coast Conserv 5:81-90

Rinaldo A, Fagherazzi S, Lanzoni S, Marani M, Dietrich WE (1999) Tidal networks 2. Watershed delineation and comparative network morphology. Water Resour Res 35(12):3905-3917
Schoelynck J, Bal K, Backx H, Okruszko T, Meire P, Struyf E (2010) Silica uptake in aquatic and wetland macrophytes: a strategic choice between silica, lignin and cellulose? New Phytol 186:385-391

Sharitz RR, Pennings SC (2006) Development of wetland plant communities. In: Batzer DP, Sharitz RR (ed) Freshwater and estuarine wetlands. University of California Press, Berkeley, p 567

Smayda TJ (1997) Harmful algal blooms: their ecophysiology and general relevance to phytoplankton blooms in the sea. Limnol Oceanogr 42:1137-1153

Struyf E, Conley DJ (2009) Silica: an essential nutrient in wetland biogeochemistry. Front Ecol Environ 7(2):88-94

Struyf E, Conley DJ (2012) Emerging understanding of the ecosystem silica filter. Biogeochemistry 107:9-18

Struyf E, Van Damme S, Gribsholt B, Meire P (2005a) Freshwater marshes as dissolved silica recyclers in an estuarine environment (Schelde estuary, Belgium). Hydrobiologia 540:69-77

Struyf E, Van Damme S, Gribsholt B, Middelburg JJ, Meire P (2005b) Biogenic silica in freshwater marsh sediments and vegetation. Mar Ecol Prog Ser 303:51-60

Struyf E, Dausse A, Van Damme S, Bal K, Gribsholt B, Boschker HTS, Middelburg JJ, Meire P (2006) Tidal marshes and biogenic silica recycling at the land-sea interface. Limnol Oceanogr 51(2):838-846

Struyf E, Temmerman S, Meire P (2007a) Dynamics of biogenic Si in freshwater tidal marshes: Si regeneration and retention in marsh sediments (Scheldt estuary). Biogeochemistry 82:41-53

Struyf E, Van Damme S, Gribsholt B, Bal K, Beauchard O, Middelburg JJ, Meire P (2007b) Phragmites australis and Si cycling in tidal wetlands. Aquat Bot 87:134-140

Struyf E, Opdekamp W, Backx H, Jacobs S, Conley DJ, Meire P (2009) Vegetation and proximity to the river control amorphous $\mathrm{Si}$ storage in a riparian wetland (Bierbza National Park, Poland). Biogeosciences 6:623-631

Sullivan MJ, Moncreiff CA (1990) Edaphic algae are an important component of salt marsh food webs: evidence from multiple stable isotope analyses. Mar Ecol Prog Ser 62:149-159

Teal JM (1962) Energy flow in the salt marsh ecosystem of Georgia. Ecology 43(4):614-624

Temmerman S, Govers G, Wartel S, Meire P (2003) Spatial and temporal factors controlling short-term sedimentation in a salt and freshwater tidal marsh, Scheldt estuary, Belgium, SW Netherlands. Earth Surf Process Landforms 28:739-755

Temmerman S, Bouma TJ, Govers G, Lauwaet D (2005) Flow paths of water and sediment in a tidal marsh: relations with marsh developmental stage and tidal inundation height. Estuaries 28(3):338-352. doi:10.1007/BF02693917

Temmerman S, Bouma TJ, Van de Koppel J, Van der Wal D, De Vries MB, Herman PMJ (2007) Vegetation causes channel erosion in a tidal landscape. Geology 35:631-634. doi:10.1130/G23502A.1

Temmerman S, Moonen P, Schoelynck J, Govers G, Bouma TJ (2012) Impact of vegetation die-off on spatial flow patterns over a tidal marsh. Geophys Res Lett 39:L03406

Tonelli M, Fagherazzi S, Petti M (2010) Modeling wave impact on salt marsh boundaries. J Geophys Res 115:C09028. doi:10.1029/2009JC006026

Torres R, Mwamba MJ, Goni MG (2003) Properties of intertidal marsh sediment mobilized by rainfall. Limnol Oceanogr 48:1245-1253

Turner RE, Baustian JJ, Swenson EM, Spicer JS (2006) Wetland sedimentation from Hurricanes Katrina and Rita. Science 314:449-452

Valiela I, Cole ML, et al. (2000) Role of salt marshes as part of coastal landscapes. In: Weinsteiner MP, Kreeger DA (ed) Concepts and controversies in tidal marsh ecology, 23. Springer, New York, p 38

Van Damme S, Struyf E, Maris T, Ysebaert T, Dehairs F, Tackx M, Heip C, Meire P (2005) Spatial and temporal patterns of water quality along the estuarine salinity gradient of the Scheldt estuary (Belgium and The Netherlands): results of an integrated monitoring approach. Hydrobiologia 540:29-45

Vieillard AM, Fulweiler RW, Hughes ZJ, Carey JC (2011) The ebb and flood of silica: quantifying dissolved and biogenic silica fluxes from a temperate salt marsh. Estuarine Coastal Shelf Sci 95:415-423

Vignudelli S, Santinelli C, Murru E, Nainnicini L, Seritti A (2004) Distributions of dissolved organic carbon (DOC) and chromophoric dissolved organic matter (CDOM) in coastal waters of the northern Tyrrhenian Sea (Italy). Estuarine Coastal Shelf Sci 60(1):133-149

Volkman JK, Revill AT, Holdsworth DG, Fredericks D (2008) Organic matter sources in an enclosed coastal inlet assessed using lipid biomarkers and stable isotopes. Org Geochem 39(6):689-710 
Voulgaris G, Meyers ST (2004) Temporal variability of hydrodynamics, sediment concentration and sediment settling velocity in a tidal creek. Cont Shelf Res 24:1659-1683

Wilson AM, Morris JT (2012) The influence of tidal forcing on groundwater flow and nutrient exchange in a salt marsh-dominated estuary. Biogeochemistry 108:27-38

Xu YP, Mead RN, Jaffe R (2006) A molecular marker-based assessment of sedimentary organic matter sources and distributions in Florida Bay. Hydrobiologia 569:179-192

Zhou J, Wu Y, Zhang J, Kang Q, Liu Z (2006) Carbon and nitrogen composition and stable isotope as potential indicators of source and fate of organic matter in the salt marsh of the Changjiang Estuary, China. Chemosphere 65 (2):310-317

doi:10.1186/2192-1709-2-3

Cite this article as: Fagherazzi et al: Fluxes of water, sediments, and biogeochemical compounds in salt marshes. Ecological Processes 2013 2:3.

\section{Submit your manuscript to a SpringerOpen ${ }^{\circ}$} journal and benefit from:

- Convenient online submission

- Rigorous peer review

- Immediate publication on acceptance

- Open access: articles freely available online

- High visibility within the field

- Retaining the copyright to your article 